\title{
Analysing the Skill of Writing a Scientific Article as a Written Communication Skill of Prospective Elementary School Teacher on Learning Mathematics
}

\author{
Dr. Agustan Syamsuddin ${ }^{1}$ \\ Dr. Sukmawati \\ Dr. Sriyanti Mustafa ${ }^{2}$ \\ Dr. Rosidah ${ }^{3}$ \\ Dr. Ma'rufi ${ }^{4}$ \\ ${ }^{1}$ Universitas Muhammadiyah Makassar, Sulawesi Selatan 90221, Indonesia \\ ${ }^{2}$ Universitas Muhammadiyah Pare-pare,Sulawesi Selatan 91112, Indonesia \\ ${ }^{3}$ Universitas Negeri Makassar,Sulawesi Selatan 90222, Indonesia \\ ${ }^{4}$ Universitas Cokroaminoto Palopo,Sulawesi Selatan 91911, Indonesia
}

DOI: https://doi.org/10.36941/jesr-2021-0108

\section{Abstract}

One of the skills developed in the 21st century learning framework is the development of written communication skills for students in higher education. Written communication is the ability to express ideas in written form with the aim of expressing ideas, solving problems, improving reasoning skills, understanding scientific phenomena and constructing the phenomena being studied. One way to make it easier for students to communicate their ideas in writing is to use reflective journals. This pre-experiment research aims to identify the written communication skill of prospective teachers of the elementary school in compiling scientific articles through a reflective journal. The research used one group pretest-posttest design which involved 20 prospective teachers of elementary school. The instrument used was a task sheet of scientific article writing. Data were processed using descriptive and inferential statistical analysis. The result showed the average value of prospective teachers' written communication skills before using a reflective journal is 52.50, and after using it is 80.56. The gain index is 0.59, which describes the score improvement of students' written communication skills in the medium category. The value of significance obtained is $0,000<0.05$. This indicated that there is an influence of the use of reflective journals in enhancing the student's written communication skills.

Keywords: written communication skill, scientific article, reflective journal

\section{Introduction}

Problem-solving is one of the skills that students must possess as an output of studying mathematics (Depdiknas, 2006; NCTM, 2000; Wheeler \& Mallam, 2020). Hence, mathematical learning should be 
prepared so that students can overcome all of the complex life problems in this 21st century (Syamsuddin, 2019). This framework illustrates that to achieve success both in the profession and in private life, students must have a provision of skills, knowledge, and expertise that is a combination of content knowledge, special skills, and proficiency. Therefore, collaboration, creativity, critical thinking, reflective thinking, and communication are the focus of mathematical learning that tremendously important to be prepared for the future of our students (Permendikbud, 2016).

According to the 21st-century framework, communication skills are one of the most important skills to develop. These skills are in detail described in the Partnership for 21st Century Skills (2009). The communication skills are intended to (1) articulate ideas effectively using oral, written and nonverbal communication in various forms and contexts; (2) effective listening to describe meanings, including knowledge, values, attitudes, and intentions; (3) use communication for various purposes (e.g. to inform, instruct, motivate and persuade/solicit); (4) utilize some media and technology and knowing how to assess its effectiveness and assess its impact; and (5) communicate effectively in diverse environments (including multi-lingual).

On the 21st-century skills map, it is stated that effective communication is the center of scientific research practice. Scientific research practices can be done through undergraduate study where undergraduate learning is a major college activity that allows universities to successfully conduct advanced research and graduate education (Bernanke, 2007). Hence, higher education is a potential institution to improve scientific publications. It is based on reports of a study by conducted by Litan et al. (2007) who reported that: (a) more than 50\% of basic research resulted in breakthrough thinking that allowed the emergence of new industries to be implemented in higher education; (b) the college has a broader mission in translating the results of Litbang into new products and companies; (c) $15 \%$ of applied research is carried out through innovations initiated on campus which are then absorbed into the business through patent, start-up, and consultancy arrangement between lecturers and industry.

According to the report, it indicates that higher education knows research and development. To conduct research, it takes reflective writing skills. Hamton (2012) states that thinking and writing reflective are an important part of campus life and work. Hamton further explained that the ability to flexion of experience and knowledge and to use it for improvement is an important part of the university's level of thought. In line with the learning framework of the 21st century, the Indonesian Government also participated in the development of written communication for students in higher education. Where education is conducted based on the principles of academic culture development through the culture of reading and writing (law of the Republic of Indonesia No. 12, 2012).

Thus, communication skills are essential for students to develop. This hope contradicts with the reality that occurs in Indonesia. It is based on the Scientific Journal Rankings (SJR) data in 2018 which records the Indonesian placed in 48th position, while Malaysia is in 34, Singapore in 32 and Thailand in 44th position. This condition caused the Indonesian government to issue a policy to increase the number of publications in Indonesia through the provisions of the publication for students who will complete their studies in the high-level, both at S1 (undergraduate), S2 (graduate) and S3 (postgraduate) (Ditjen Dikti, 2012). From this policy, students are expected to be able to pour the idea of their writings through written communication in the form of a scientific article.

Written communication is closely related to the ability to pour ideas in written form so it takes the ability to write as a form of scientific communication which is the result of thought from a person working on the cognitive area (Sinclair, 2010). By writing activities, one can convey ideas, solve problems, and understand the change of the world. Also, the writing activity is one means of selfexpressing (Eroglu, 2019; Lambirth \& Goouch, 2006). The writing activity itself is a bridge to know the description of the future so that students can prepare themselves for their academic (Wanket, 2005; Sulak, 2018). In mathematics learning, the ability of written communication helps students to improve reasoning ability (Avci \& Uslu, 2009; Cardetti \& LeMay, 2019; Freeman, Higgins, \& Horney, 2016; Rofiki et al., 2017) and understand the phenomenon of the scientific phenomenon (Avci, 20o8; Avci \& Bayrak, 2013; Brozo \& Crain, 2018; Rodríguez-Martínez, González-Calero, \& Sáez-López, 2019; 
Stevens, Mills, \& Kuchel, 2019). One way to facilitate students to communicate their ideas in writing is by using a journal (Avci, 2008; Avci \& Uslu, 2009).

This writing strategy helps students to realize the misconception and construct their conceptual knowledge (Hand, Hohenshell, \& Prain, 2004). To enable students to build their knowledge, the emphasis of writing performed by students should be based on reflections about their knowledge and experience (Hand, Prain, \& Wallace, 2002). Thus, reflective writing can help students to actively learn and enhance their textual learning materials (Huang \& Kalman, 2012; Kalman, Aulls, Rohar, \& Godley, 2008). Reflective writing can be seen as a writing activity that explores the problems triggered by experiences that allow a person to view something from the other side (Brockbank \& McGill, 2007). The results of this integration can improve the conceptual understanding of students in collecting and analyzing and interpreting data based on the results of the experiment that students performed in the learning process (Lee, Woods \& Tonissen, 2011). This learning environment will have an impact on the career and professional development of the students in the future (McCarthy, 2011). Thus, a teacher must have written communication skills in the form of scientific writings as part of their career development or their profession.

Regarding career development and professionalism of a teacher in case of their the ability in written communication in the form of scientific writing is regulated in the decree of the Minister of State Apparatus Reform number 118/1996 about the functional department of Teachers and their credit numbers, and the joint decision of the Minister of Education and Culture and head of the BKKN number 0433/P/1993, number 25 the year 1993. It is even more urgent with the release of Permenegpan No. 16 of 2009 which governs the mandatory conditions that affect the promotion and welfare level of a teacher.

However, teachers find it difficult to communicate ideas in the form of scientific writings. This is evident from the large number of teachers who have difficulty in getting credit in the case of scientific writings. As a consequence, the professional career development of several teachers was hampered. If during this time the promotion of teachers takes place periodically and smoothly, which is every two years, in the process of promotion/group IV/a to IV/b is not so. The official data of the Depdiknas year 2006 shows that the number of teachers stuck in their career (stuck in IV/a) as many as 334,184 people. Meanwhile, 347,565 teachers in the status of III/d are queued in reaching the level of IV/a. The number of teachers who are in IV/b only 2,318 people (under 1\%) (Kompasiana, 2013).

The data appeared that the writing tradition among teachers is still weak and also is less motivated in writing. This is why communicating ideas in the form of scientific communication for prospective teachers needs to be traced. Therefore, a vitamin is needed to foster awareness of teachers to write a scientific paper. One of the alternatives that can be done is to practice the students' written communication skills that are poured out in the form of scientific articles through reflective journals. This activity may increase students' inquiry in terms of scientific journal writings (Dyment \& O'connel, 2010). One strategy that can be used to practice students' scientific communication skills through the analysis of the article content of a reading journal. With the analysis of the journal content, students can try to understand and do innovation from the article that is read to construct a different research idea of the article being studied. Therefore, it takes the integration of experience in conducting future actions (Higgins, Aitken-Rose, \& Dixon, 2009) in the form of constructing new ideas from the analysis of the content in the articles studied.

The development of students' written communication skills in the form of scientific article writing through reflective journals can be used as a strategy to encourage and to develop students' skills in developing their new ideas as a reduced activity even eliminating the potential of plagiarism among students. To determine the impact of the use of reflective journals on written communication skills students need to be traced further. Therefore, the study aims to improve the written communication skills of elementary school teacher students in writing scientific articles through reflective journal. 


\section{Methodology}

\subsection{Research Design}

This research is a pre-experiment study using the one group pretest-posttest design. The research design is adapted from experimental research design developed by Fraenkel, Hyun and Wallen (2012).

\begin{tabular}{ccc}
\hline $\mathrm{O}_{1}$ & $\mathrm{X}$ & $\mathrm{O}_{2}$ \\
Pretest & Treatment & Posttest \\
\hline
\end{tabular}

Description:

$\mathbf{O}_{\mathbf{1}}=$ score of the written communication skill of prospective teacher of elementary school before using a reflective journal (pretest).

$\mathbf{X}=$ learning by integrating reflective journal in the task of writing scientific article.

$\mathbf{O}_{2}=$ score of the written communication skill of prospective teacher of elementary school after using a reflective journal (posttest).

\subsection{Research Goal}

The aim of this research to identify and analyze the written communication skill of prospective teacher of the elementary school in writing scientific article through a reflective journal about mathematics learning in elementary school.

\subsection{Sample and Data Collection}

This research involved 20 prospective teachers of the elementary school in Universitas Muhammadiyah Makassar who programmed the course "Mathematics Learning Studies in Primary Schools". This is done to train students' skills in identifying problems in learning mathematics for elementary school students and trying to find solutions to these problems with the support of learning theory and empirical data that prospective teachers of the elementary school get at school.

The instrument used was a task sheet of writing scientific article which were used to practice the written communication skills of prospective teachers of the elementary school in order to write scientific articles through reflective journals are as follows.

Table 1: Task sheet of writing scientific article

\begin{tabular}{|c|c|c|c|c|}
\hline $\begin{array}{l}\text { Author, year, title, } \\
\text { Source (journal name, } \\
\text { Text Book) } \\
\end{array}$ & $\begin{array}{c}\text { Research objectives, } \\
\text { scientific writing } \\
\text { objectives }\end{array}$ & $\begin{array}{cc}\begin{array}{c}\text { Foundation } \\
\text { theory }\end{array} & \begin{array}{c}\text { Research methods to data } \\
\text { analysis techniques (if } \\
\text { any) }\end{array} \\
\end{array}$ & $\begin{array}{l}\text { Research result, main } \\
\text { meaning of content in } \\
\text { text book } \\
\end{array}$ & Description \\
\hline \multicolumn{5}{|c|}{ Reading results related to journal articles/text book that can be used (things that can be used in writing your article) } \\
\hline
\end{tabular}

Note

The aspect measured in this instrument were (1) the ability of students to identify the purpose of scientific writing of the articles analyzed, (2) The ability of the student to identify the research method (data analysis technique) of the reviewed article, (3) students' ability to identify the results of the study, the main meaning of the article being read, (4) the students' ability to summarize the article, (5) the ability of the student to construct a new idea of the article reading, (6) students' ability 
to write scientific articles. In detail, the following assessments of students' written communication skills were measured through a task sheet of writing scientific article outlined in the Table 2 .

Table 2: Student's written communication assessment rubric

\begin{tabular}{|c|c|c|}
\hline Aspect & Criteria & Score \\
\hline \multirow{3}{*}{$\begin{array}{l}\text { Ability to identify the objective of } \\
\text { scientific writings }\end{array}$} & Able to identify research objectives of the reviewed articles, clearly and concise. & 3 \\
\hline & Able to identify research objectives of the article that is studied but less clearly written. & 2 \\
\hline & Less precise in identifying research objectives of the articles & 1 \\
\hline \multirow[t]{3}{*}{$\begin{array}{l}\text { Ability to identify research method } \\
\text { (data analysis technique) }\end{array}$} & $\begin{array}{l}\text { Able to identify research methods from articles that are examined clearly, and written } \\
\text { concisely. }\end{array}$ & 3 \\
\hline & Able to identify research methods of articles that are studied but less clearly written. & 2 \\
\hline & Less precise in identifying research method of the reviewed article. & 1 \\
\hline \multirow[t]{3}{*}{$\begin{array}{l}\text { Ability to identify research findings, } \\
\text { the main content of article }\end{array}$} & $\begin{array}{l}\text { Able to clearly identify research findings from the reviewed article and the written are clear } \\
\text { and concise. }\end{array}$ & 3 \\
\hline & Able to identify research results from articles that are reviewed but less clearly written. & 2 \\
\hline & Less precise in identifying research findings of the reviewed article. & 1 \\
\hline \multirow[t]{3}{*}{ Ability to summarize article } & Clearly and concisely summarize the research findings from the reviewed article & 3 \\
\hline & Summarize the research findings of the reviewed article but less clearly written. & 2 \\
\hline & Less precise in writing the summary of the research article studied. & 1 \\
\hline \multirow{3}{*}{$\begin{array}{l}\text { Ability to construct new idea from the } \\
\text { read article that has been studied }\end{array}$} & Able to construct new ideas based on the reviewed article & 3 \\
\hline & Able to construct new ideas from articles that are reviewed but less clearly written & 2 \\
\hline & Unable to construct new ideas from reviewed articles & 1 \\
\hline \multirow[t]{3}{*}{ Ability of writing scientific article } & $\begin{array}{l}\text { Write the research objective, relevant theories, research method used and research findings in } \\
\text { a clear and concise way and using complex but effective sentences. }\end{array}$ & 3 \\
\hline & $\begin{array}{l}\text { Write the research objective, relevant theories, research method and research findings, in a } \\
\text { clear way but less logic and less precise with simple sentences but effective. }\end{array}$ & 2 \\
\hline & $\begin{array}{l}\text { Write research methods, relevant theories, and research findings in illogical way and is not } \\
\text { precise with sentence construction that is not obvious and the confusing meaning, }\end{array}$ & 1 \\
\hline
\end{tabular}

\subsection{Data Analysis}

Furthermore, the results of the written communication skills test of prospective teachers of the elementary school that have been collected from this study were processed using statistical analysis which are descriptive statistical analysis and inferential statistical analysis. Descriptive analysis by using descriptive statistical analysis is used to analyze the data to get an overview of students' written communication skills through reflective journals. The descriptive statistical analysis used is the highest value and lowest value, the average value, the standard deviation that is spelled out through the frequency distribution table. Meanwhile, in the inferential statistical analysis meant to test the research hypothesis that was previously expressed which is the impact of the use of reflective journals to the students' skill in written communication. Before testing hypotheses, prerequisite data test was initially conducted. It was aimed to test data nomalities and the homogenity. In the hypothesis test, t-test is carried out. Calculations are done using t-test (one sample t-test) with a significance level of 0.05 .

Subsequently, to identify an increase of the written communication skills test of prospective teachers of the elementary school through journal reflective then the gain index calculation is conducted. In this study, the gain index would be used when the average value before and after the treatment was different.

The gain index formula used in this study is as follows. gain $(d)=\frac{\mathrm{o}_{2-} \mathrm{o}_{1}}{\text { possible maximum score- } \mathrm{o}_{1}}(\mathrm{l})$

Description:

$\mathrm{O}_{1}=$ pretest measurement result

$\mathrm{O}_{2}=$ posttest measurement result

The criteria for increasing pretest and posttest value related to students' written communication skills through reflective journals is outlined in the following Table 3 which adapted from Hake (1999). 
Table 3: Gain index interpretation criteria

\begin{tabular}{lc}
\hline The value "d" Gain & Interpretation \\
\hline $\mathrm{d}>0,7$ & High \\
$\mathrm{o}, 3 \leq \mathrm{d} \leq \mathrm{o}, 7$ & Moderate \\
$\mathrm{d}<0,3$ & Poor \\
\hline
\end{tabular}

\section{Findings and Discussion}

This research paper identifies the difference in students' the written communication skill of prospective teachers for elementary school before and after implementing journal reflective in learning process. Therefore, task sheet of writing scientific article about mathematical learning in elementary school is used to measure the written communication skill of prospective teachers.

The average value of the written communication result (writing scientific article) for pretest is 52.50. Meanwhile, the average value of written communication skills' result (writing scientific paper) for posttest of students is 80.56. The ability to write article students on pretests activities are in the very poor category whilst for activities posttest, the ability to write article students are in high category. The determination of this category is based on the five-scale conversion guidelines on the students' ability to write articles as written communication skills outlined in the Table 4 .

Table 4: Five-scale conversion guidelines on students' written communication skill

\begin{tabular}{cc}
\hline Score Interval & Criteria \\
\hline $90-100$ & Very High \\
$80-89$ & High \\
$70-79$ & Fair \\
$60-69$ & Poor \\
$50-59$ & Very Poor \\
\hline
\end{tabular}

The following are presented data regarding students' written communication skill in the Table 5 .

Table 5: Recapitulation of the students' written communication skill

\begin{tabular}{lcc}
\hline Data & $\begin{array}{c}\text { Score of Students' Written Communication Skills } \\
\text { Pretest }\end{array}$ & $\begin{array}{c}\text { Posttest } \\
\text { Maximum Value }\end{array}$ \\
Minimum Value & 77.78 & 100 \\
Mean & 33.33 & 50 \\
Median & 52.50 & 80.56 \\
Mode & 50.00 & 83.33 \\
Deviation Standard & 50.00 & 83.33 \\
\hline
\end{tabular}

Based on the Table 5, the size of centration and data dissemination of pretests and posttest results related to students' written communication skills appears that there is an increase in points of 28.06. This indicates that there is an increase in writing scientific article as written communication skill of prospective teachers. To support this statement, it is necessary to do hypotheses proposed earlier by comparing the average written communication skill in the form of writing a scientific article before using a reflective journal (pretest) and an average student's writing communication skill in the form of writing a scientific article after using a reflective journal (posttest). Afterwards, to test the hypotheses, inferential statistical analysis with one sample t-test was conducted. Prior to analyze ttest, the prerequisite test was conducted which are the test of normality and homogeneity. The following presented data regarding the prerequisite tests that have been conducted on this research. 


\subsection{Normality Test}

Table 6: Tests of normality

\begin{tabular}{lccccccc}
\hline & Class & \multicolumn{2}{c}{ Kolmogorov-Smirnov(a) } & \multicolumn{3}{c}{ Shapiro-Wilk } \\
\hline Normality & & Statistic & Df & Sig. & Statistic & df & Sig. \\
& Pretest & .227 & 20 & .008 & .939 & 20 & .235 \\
& posttest & .142 & 20 & $.200\left(^{*}\right)$ & .944 & $\mathbf{2 0}$ & .287 \\
\hline
\end{tabular}

From the Table 6, it is obtained that all distributed data is normal. Data pretests obtained significance $0.235>0.05$ so that the distributed data is normal, while the posttest data obtained 0.287 $>0.05$ which indicates that the distributed data is normal.

\subsection{Homogeneity Test}

Table 7: Test of homogeneity of variances

\begin{tabular}{llll}
\hline Levene Statistic & $\mathrm{dfi}$ & $\mathrm{df} 2$ & Sig. \\
\hline .007 & 1 & 38 & .932 \\
\hline
\end{tabular}

Based on the results of a homogeneity test based on Table 6, data are homogeneous with significance $0.932>0.05$. Furthermore, the result of hypothesis test is presented in Table 8 .

Table 8: One-sample t-test

\begin{tabular}{lcccccc}
\hline & \multicolumn{6}{c}{ Test Value $=0$} \\
\cline { 2 - 7 } & $\mathrm{T}$ & Df & Sig. (2-tailed) & $\begin{array}{c}\text { Mean } \\
\text { Difference }\end{array}$ & $\begin{array}{c}\text { 95\% Confidence Interval } \\
\text { of the Difference }\end{array}$ \\
\cline { 2 - 7 } & Lower & Upper & Lower & Upper & Lower & Upper \\
\hline $\begin{array}{l}\text { Students' written } \\
\text { communication skill }\end{array}$ & $\mathbf{2 2 . 1 2 5}$ & 39 & .0oo & 66.52778 & 60.4459 & 72.6097 \\
\hline
\end{tabular}

Based on the Table 8, it is derived significance $0.000<0.05$ so the hypothesis is acceptable. Thus, it can be argued that the average communication ability written in the form of scientific article writing before using reflective journal (pretest) is lower than average student's written communication ability in the form of writing scientific article after using reflective journal (posttest). This explains that there is an increase in the quality of student written communication skills through the writing activities of scientific article using reflective journal. For more details, here are outlined improved scores of scientific articles writing skill that can be seen from the gain index calculations of pretests and posttest results. gain $(d)=\frac{8.55-52.50}{100-52.50}=\frac{28.05}{47.50}=0.59$

The gain index obtained is 0.59 . Prospective teachers' written communication skill scores in the form of scientific articles through reflective journal is in a fair category. This indicates that there has been an increase in the scores of students' written communication skills in the form of scientific articles using a reflective journal so that it supports the hypothesized testing previously stated. The improvement of the students' written communication skills in several aspects is the ability to identify research objectives and foundation theory used in articles that are read or discussed. Similarly, the ability of students to identify the research methods to the analysis techniques used so that students can use or develop either instruments or data collection techniques or data analysis techniques used to produce a description or a picture of great research results that certainly fulfill scientific writings. Also, students have the idea to construct new research ideas so that students have their own space to 
conduct research according to their students' abilities and interests.

The study suggested that students' written communication skills can be enhanced or trained by mentoring and learning using reflective journals. Through reflective journal, prospective teachers of elementary school are allowed to utilize any things that can be used in communicating ideas in the form of scientific writing which is the result of reading journal articles/textbooks. Besides, they can also investigate what is expected, but not found in the journal or the text which previously studied, so that it should be searched in other sources. If then, the student does not find it, this can be a new finding that they can make as a topic/sub-topic of their scientific writing as a result of communicating ideas in the scientific work they are making. Hence, students can construct new ideas from some of the articles studied. This can improve students' ability to communicate their ideas in writing than without using a reflective journal beforehand.

It is in line with a study conducted by Lee, Woods, and Tonissen (2011) stating that with the use of journals, student communication skills can increase significantly. Furthermore, they stated that the students' communication skills increased due to the introduction of how to write simple writing activities combined in the learning process in the classroom. Further, students have a great curiosity to the materials studied so that they are trying to find a solution from each issue studied by looking for several references that support research ideas as well as implementation plans and research results obtained. Therefore, using reflective journal, student can identify all aspects needed in writing a scientific article.

Moreover, it is also confirmed by the research findings of Dyment \& O'connel (2010) which suggests that the use of reflective journals can increase inquiry or students' discoveries showed by the variety of their research ideas. Thus, with a reflective journal helps students to construct the research idea in order to write scientific papers which can practice the skills of scientific articles writing of students as one of the traits in learning at higher education (McCarhty, 2011; Nilsson \& Karlsson, 2019; Osborne, 2019; Sternberg \& Sternberg, 2010; Sweet, Bass, \& Graham, 2019). This gives the contribution in order to prepare the students' environment that can write reflective scientific articles that affect the development of their future career and professional development.

Through this activity, prospective teachers of elementary school are also skilled in drafting simple sentences and attempting to raise an idea or research problem and strive to seek the breakdown of the problems. Similarly, the research results from Belden, Russonello \& Stewart (2005) stating that writing activities are believed that it can improve other skills especially reading, communication, grammar, vocabulary, critical thinking, and analytical skills. If the writing activity integrated into mathematical learning, the use of writing strategy can improve students' ability in solving a problem, reasoning, proving, communication, connection, and representation in learning as well as solving a mathematical problem (Lee, Lim \& Leong, 2020; McCormick, 2010). Besides, students can explain the phenomenon or problems that occur in a learning activity (Mcneill, 2009). It is, therefore, writing skill is tremendously needed to train problem-solving skill in mathematical learning (Syamsuddin, 2020a; Syamsuddin, 202ob; Syamsuddin, Juniati \& Siswono, 2020).

Learning by using reflective journals to practice writing skills of prospective teacher of elementary school on the topic of learning mathematics provides opportunities for students to try to express ideas in identifying problems in learning mathematics in elementary schools. In addition, students have skills in conducting critical analysis on several references which are used as sources for constructing new ideas in finding solutions to learning problems obtained at school. Therefore, learning using this reflective journal can be used as a learning model in order to improve students' scientific article writing skills. It is necessary to develop a form of training model in order to create an academic atmosphere for prospective elementary school teachers that motivates them to like reading, analyzing, reasoning and creating new innovations in order to solve problems from various problems identified from reading results and criticize some reading sources which student studies. 


\section{Conclusion}

The result reveals that scientific writing as a form of written communication skill from prospective teacher of elementary school is not an easy work. It happens due to the low writing tradition among elementary school teacher students to write a scientific article. Hence, we need a vitamin that can raise the awareness of prospective teachers of elementary school to possess written communication skills. One of them is through a reflective journal that can help them to structure their ideas which will be easy for them to write their ideas in scientific writings. By using a reflective journal, the ability to write scientific articles of prospective teachers of elementary school is an improvement in which the results of pretests are in a very low category while for posttest results are in the high category. Besides, the increased scores of pretests and posttest activities are in a medium based on gain index calculations related to the student's ability to write scientific articles. To conclude, reflective journal can improve student's written communication skills. By using a reflective journal, prospective teachers of elementary school are successfully improved where the pretest result is in a very poor category while the posttest result is in a high category. Moreover, the increase of pretest and posttest are in a fair category which is based on gain index calculation regarding students' ability to write a scientific article. Thus, it can be concluded that reflective journal can enhance students' written communication skill.

\section{References}

Avci, D. E. (2008). The use of student journals in science and technology education. Eurasian Journal of Educational Research (EJER), 8(30), 17-32.

Avc1, D. E., \& Bayrak, E. B. (2013). Investigating teacher candidates 'opinions related to scenario-based learning: An action research. Elementary Education Online, 12(2), 528-549. http://ilkogretim-online.org.tr/index.php /io/article/view/1418/1274

Belden, N., Russonello, J., \& Stewart, K. (2005). Learning to write, learning to learn: Americans' views of writing in our schools. A Report of a National Public Opinion Survey. The National Writing Project.

Bernanke, B. (2007). Education and economic competitiveness. US: Board of Governors of the Federal Reserve System. https://www.federalreserve.gov/newsevents/speech/bernanke20o70924a.htm.

Brockbank, A., \& McGill, I. (2007). Facilitating reflective learning in higher education. UK: McGraw-Hill Education. https://books.google.co.id/books?id=S3Ir9ZcHFn8C

Brozo, W. G., \& Crain, S. (2018). Writing in math: A disciplinary literacy approach. The Clearing House: A Journal of Educational Strategies, Issues and Ideas, 91(1), 7-13. https://doi.org/10.108o/ooog8655.2017.1342435

Cardetti, F., \& LeMay, S. (2019). Argumentation: Building students' capacity for reasoning essential to learning mathematics and sciences. PRIMUS, 29(8), 775-798. https://doi.org/10.1080/10511970.2018.1482581

Cargill, M., \& O'Connor, P. (2013). Writing scientific research articles: Strategy and steps. John Wiley \& Sons. https://www.wiley.com/en-au/Writing+Scientific+Research+Articles\%3A+Strategy+and+Steps\% ${ }_{2} \mathrm{C}+2$ nd+Editionp-9781118570708

Depdiknas. (2006). Peraturan Menteri Pendidikan Nasional No. 22 Tahun 2006 Tentang Standar Isi Untuk Satuan Pendidikan Dasar dan Menengah. Jakarta: Depdiknas. https://bsnp-indonesia.org/wp-content/uploads /isi/Permen_22_2006.pdf.

Dikti. (2012). Kebijakan ditjen pendidikan tinggi tentang KKNI dan arah kurikulum LPTK. Jakarta: Dikti. https://lldikti11.ristekdikti.go.id/download/pdf/693.

Dyment, J. E., \& O'Connell, T. S. (2010). The quality of reflection in student journals: A review of limiting and enabling factors. Innovative Higher Education, 35(4), 233-244. https://doi.org/10.1007/s10755-010-9143-y.

Erduran Avc1, D., \& Uslu, H. (2009). Students' opinions about writing journal in science-technology and mathematics lessons. In G. Cakmakci \& M.F. Tașar (Eds.), Contemporary science education research: learning and assessment (pp. 361-368). Ankara, Turkey: Pegem Akademi.

Eroglu, M. A. (2019). Integrating digital tools for teaching of writing expression in Turkish language. International Journal of Learning and Teaching, 11(1), 34-41. https://doi.org/10.18844/ijlt.v11i1.1031

Fraenkel, J. R., Hyun, H. H., \& Wallen, N. E. (2012). The research problem. How toDesign and Evaluate Research in Education (8th ed.) New York: McGraw Hill. 
Freeman, B., Higgins, K. N., \& Horney, M. (2016). How students communicate mathematical 1deas: An examination of multimodal writing using digital technologies. Contemporary Educational Technology, 7(4), 281-313. https://files.eric.ed.gov/fulltext/EJ1117603.pdf.

Hake, R. R. (1999). Analyzing change/gain scores. Unpublished.[online] URL: http://www. physics. indiana. edu/ sdi/AnalyzingChange-Gain. pdf.

Hamton, M. (2012). Reflective thinking and writing. University of Portsmouth.

Hand, B., Hohenshell, L., \& Prain, V. (2004). Exploring students' responses to conceptual questions when engaged with planned writing experiences: A study with year 10 science students. Journal of Research in Science Teaching: The Official Journal of the National Association for Research in Science Teaching, 41(2), 186-210. https://doi.org/10.1002/tea.10128

Hand, B., Prain, V., \& Wallace, C. (2002). Influences of writing tasks on students' answers to recall and higherlevel test questions. Research in Science Education, 32(1), 19-34. https://doi.org/10.1023/A:1015098605498

Higgins, M., Aitken-Rose, E., \& Dixon, J. (2009). The pedagogy of the planning studio: A view from down under. Journal for Education in the Built Environment, 4(1), 8-30. https://doi.org/10.11120/jebe.2009.04010008

Huang, X., \& Kalman, C. S. (2012). A case study on reflective writing. Journal of College Science Teaching, 42(1), 92-99.

Kalman, C., Aulls, M. W., Rohar, S., \& Godley, J. (2008). Students' perceptions of reflective writing as a tool for exploring an introductory textbook. Journal of College Science Teaching, 37(4), 74.

Kompasiana. (2013). Guru dan persoalan menulis PTK. (Online). http://www.kompasiana.com/ rujakcingurdaribraggroad/guru-dan-persoalan-menulis-ptk. Accessed August 20, 2015.

Lambirth, A., \& Goouch, K. (2006). Golden times of writing: The creative compliance of writing journals. Literacy, 40(3), 146-152. https://doi.org/10.1111/j.1467-9345.2006.00427.x

Lee, G. P. B., Lim, C. S., \& Leong, L. M. (2020). Use mathematical writing as a practical approach to increase students' problem-solving skills: A case study. The Mathematics Enthusiast, 17(1), $239-273$. https://scholarworks.umt.edu/tme/voli7/iss1/10

Lee, S. E., Woods, K. J., \& Tonissen, K. F. (2011). Writing activities embedded in bioscience laboratory courses to change students' attitudes and enhance their scientific writing. Eurasia Journal of Mathematics, Science $\mathcal{E}$ Technology Education, 7(3), 193-202. https://doi.org/10.12973/ejmste/75191

Litan, R. E., Mitchell, L., \& Reedy, E. J. (2007). Commercializing university innovations: Alternative approaches. Innovation policy and the economy, 8, 31-57. https://www.journals.uchicago.edu/doi/abs/10.1086 /ipe.8.25056198

McCarthy, J. (2011). Reflective writing, higher education and professional practice. Journal for Education in the Built Environment, 6(1), 29-43. https://doi.org/10.1112o/jebe.2011.06010029

Mcneill, K. L. (2009). Teachers' use of curriculum to support students in writing scientific arguments to explain phenomena. Science Education, 93(2), 233-268. https://doi.org/10.1002/sce.20294

NCTM. (2000). Principle and standards for school mathematics. Reston: The National Council of Teacher Mathematics, Inc. https://www.nctm.org/Standards-and-Positions/Principles-and-Standards/

Nilsson, P., \& Karlsson, G. (2019). Capturing student teachers' pedagogical content knowledge (PCK) using CoRes and digital technology. International Journal of Science Education, 41(4), 419-447. https://doi.org/10.108o/o9500693.2018.1551642

Osborne, J. F., Borko, H., Fishman, E., Gomez Zaccarelli, F., Berson, E., Busch, K. C., \& Tseng, A. (2019). Impacts of a practice-based professional development program on elementary teachers' facilitation of and student engagement with scientific argumentation. American Educational Research Journal, 56(4), $1067-1112$. https://doi.org/10.3102/0002831218812059.

Partnership for 21st Century Skills. (2009). P21 framework definitions. Retrieved from http://www.p21.org/storage/documents/P21_Framework_Definitions.pdf

Permendikbud. (2016). Peraturan menteri pendidikan dan kebudayaan Republik Indonesia nomor 20 tahun 2016 tentang standar kompetensi lulusan pendidikan dasar dan menengah. Jakarta: Menteri Pendidikan Nasional. https://bsnp-indonesia.org/wp-content/uploads/2009/o4/Permendikbud_Tahun2016_Nomoro2o.pdf

Permenegpan. (2009). Peraturan menteri negara pendayagunaan aparatur negara dan reformasi birokrasi nomor 16 tahun 2009 tentang jabatan fungsional guru dan angka kreditnya. Jakarta: Citra Umbara. https://jdih.menpan.go.id/data_puu/PERMENPAN2009_o16.pdf

Permenegpan. (1996). Keputusan menteri negara pendayagunaan aparatur negara nomor 118/1996 tentang jabatan fungsional pengawas sekolah dan angka kreditnya. Jakarta: MENPAN. https://jdih.menpan.go.id/data_puu/permenpan2o10_o21.pdf

Presiden, R. I. (2012). Undang-Undang Republik Indonesia no. 12 tahun 2012 tentang pendidikan tinggi. Jakarta: Armas Duta Jaya. https://dpr.go.id/dokjdih/document/uu/UU_2012_12.pdf 
Rodríguez-Martínez, J. A., González-Calero, J. A., \& Sáez-López, J. M. (2019). Computational thinking and mathematics using Scratch: an experiment with sixth-grade students. Interactive Learning Environments, 28(3), 316-327, https://doi.org/10.1080/10494820.2019.1612448.

Rofiki, I., Nusantara, T., Subanji, \& Chandra, T. D. (2017). Exploring local plausible reasoning: The case of inequality tasks. Journal of Physics: Conference Series, 943(1), 012002. https://iopscience.iop.org/article/10.1088/1742-6596/943/1/012002

Sweet, L., Bass, J., \& Graham, K. (2019). The continuity of care experience and reflective writing: Enhancing postpracticum learning for midwifery students. In Augmenting Health and Social Care Students' Clinical Learning Experiences (pp. 141-162). Springer, Cham. https://researchnow.flinders.edu.au/en/publications /the-continuity-of-care-experience-and-reflective-writing-enhancin

Sinclair, R. S. (2010). Thinking and writing: Cognitive science and intelligence analysis. Washington, DC: Center for the Study of Intelligence.https://www.cia.gov/static/9e870eco99fc6192e2e412bee248257e/Thinking-andWriting.pdf

Sternberg, R. J., \& Sternberg, K. (2010). The psychologist's companion: A guide to writing scientific papers for students and researchers. New York: Cambridge University Press. https://doi.org/10.1017/CBO9780511762024

Stevens, S., Mills, R., \& Kuchel, L. (2019). Teaching communication in general science degrees: highly valued but missing the mark. Assessment $\mathcal{E}$ Evaluation in Higher Education, 44(8), $1163-1176$. https://doi.org/10.1080/02602938.2019.1578861

Sulak, S. E. (2018). Investigation of Writing Habits of Primary School Teachers. International Electronic Journal of Elementary Education, 10(4), 497-504. https://doi.org/10.26822/iejee.2018438140. Retrieved from https://www.iejee.com/index.php/IEJEE/article/view/423.

Syamsuddin, A., (2019). The impact of implementing the INSTAD model toward student's mathematics learning outcomes for 5 th grade elementary school students. Journal of Physics: Conference Series 1318(1), 012021, IOP Publishing. [https://doi:10.1088/1742-6596/1318/1/o12021]https://doi:10.1088/1742-6596/1318/1/o12021

Syamsuddin, A. (2020a). Describing taxonomy of reflective thinking for field dependent-prospective mathematics teacher in solving mathematics problem. International Journal of Scientific E Technology Research, 9(3), 4418-4421. https://www.ijstr.org/final-print/mar2020/Describing-Taxonomy-Of-Reflective-Thinking-ForField-Dependent-prospective-Mathematics-Teacher-In-Solving-Mathematics-Problem.pdf

Syamsuddin, A. (2020b). Identifikasi kedalaman berpikir reflektif calon guru matematika dalam pemecahan masalah matematika melalui taksonomi berpikir reflektif berdasarkan gaya kognitif. Jurnal Elemen, 6(1), 128145. https://doi.org/10.29408/jel.v6i1.1743

Syamsuddin, A., Juniati, D., \& Siswono, T. Y. E. (2020). Understanding the problem-solving strategy based on cognitive style as a tool to investigate reflective thinking process of prospective teacher. Universal Journal of Educational Research, 8(6), 2614-2620. https://doi.org/10.13189/ujer.2020.080644

Wanket, M. O. L. (2005). Building the habit of writing. Educational Leadership, 63(1), 74-76. https://eric.ed.gov/?id=EJ725905

Wheeler, A., \& Mallam, W. (2020). Examining type and quality of preservice teachers' lessons based on children's literature. International Journal on Teaching and Learning Mathematics, 3(1), 1-11. https://doi.org/10.1886o/ijtlm.v3i1.9206. 